\title{
PENGENCERAN SABUN CAIR CUCI TANGAN TERHADAP ANGKA LEMPENG TOTAL BAKTERI (ALTB) TELAPAK TANGAN
}

\author{
Ziana Dia Ningsih ${ }^{1}$, Ida Bagus Ray Wiadnya ${ }^{2}$, Lale Budi Kusuma Dewi ${ }^{2}$ \\ ${ }^{1-3}$ JurusanAnalisKesehatan, Poltekkes Kemenkes Mataram, Indonesia
}

\begin{tabular}{l} 
Article Info \\
\hline Article history: \\
Received Des $12^{\text {th }}, 2017$ \\
Revised Des $20^{\text {th }}, 2017$ \\
Accepted Feb $27^{\text {th }}, 2018$ \\
\hline
\end{tabular}

\section{Keyword:}

Hand washing,

Total Bacterial Plate Number

(ALTB),

Dilution,

\begin{abstract}
Hand washing liquid soap provided in various public facilities has undergone different dilution processes. Dilution of hand washing liquid soap changes $\mathrm{pH}$, antiseptic and antibacterial concentrations as an additional content dissolved in soap so that it will affect the ability of the soap to inhibit and kill bacteria. To determine the effect of dilution of hand washing liquid soap on the palm total plate number (ALTB) of the hand. This research is descriptive observational with the design of One Group Pretest Posttest and uses Non Random Purposive Sampling technique which is then examined by the pour plate. Total Bacterial Plate Number (ALTB) obtained after hand washing with $100 \%$ soap concentration as much as Cfu / ml, at $80 \%$ soap concentration as much as $\mathrm{Cfu} / \mathrm{ml}$, at $40 \%$ soap concentration as much as Cfu / $\mathrm{ml}$ at $40 \%$ soap concentration as much Cfu / $\mathrm{ml}$ at $10 \%$ soap concentration as much as $\mathrm{Cfu} / \mathrm{ml}$. There is an effect of dilution of hand washing liquid soap against the Total Bacterial Plate (ALTB) Number of the palm.
\end{abstract}

\begin{abstract}
ABSTRAK
Sabun cair cuci tangan disediakan diberbagai fasilitas umum sudah mengalami proses pengenceran dengan jumlah yang berbeda-beda. Pengenceran sabun cair cuci tangan mengubah $\mathrm{pH}$, konsentrasi antiseptik dan antibakteri sebagai kandungan tambahan yang terlarut di dalam sabun sehingga akan mempengaruhi kemampuan sabun dalam menghambat dan membunuh bakteri. Tujuan penelitian ini adalah untuk mengetahui pengaruh pengenceran sabun cair cuci tangan terhadap Angka Lempeng Total Bakteri (ALTB) telapak tangan. Penelitian ini bersifat Observasional Deskriptif dengan rancangan One Group Pretest Posttest dan menggunakan teknik pengambilan sampel Non Random Purposive Sampling yang kemudian diperiksa dengan metode cawan tuang. Hasil penelitian ini didapatkan Angka Lempeng Total Bakteri (ALTB) telapak tangan setelah mencuci tangan dengan konsentrasi sabun $100 \%$ sebanyak Cfu/ml, pada konsentrasi sabun $80 \%$ sebanyak $\mathrm{Cfu} / \mathrm{ml}$, pada konsentrasi sabun $40 \%$ sebanyak $\mathrm{Cfu} / \mathrm{ml}$ pada konsentrasi sabun $40 \%$ sebanyak $\mathrm{Cfu} / \mathrm{ml}$ pada konsentrasi sabun $10 \%$ sebanyak $\mathrm{Cfu} / \mathrm{ml}$. Ada pengaruh pengenceran sabun cair cuci tangan terhadap Angka Lempeng Total Bakteri (ALTB) telapak tangan.
\end{abstract}

Kata Kunci : Pengenceran; Sabun Cair Cuci Tangan; Angka Lempeng Total Bakteri (ALTB)

Copyright $@$ JurnalAnalisMedika Bio Sains

\footnotetext{
Pendahuluan

Sanitasi total berbasis masyarakat (STBM) adalah suatu strategi atau program intervensi yang menitik beratkan pada pencapaian kondisi sanitasi total di masyarakat melalui perubahan perilaku higienis, dengan melibatkan seluruh komponen di masyarakat. Salah satu dari lima pilar perilaku hidup bersih dan sehat dalam sanitasi total berbasis masyarakat adalah cuci tangan pakai sabun. Perilaku cuci tangan terlebih cuci tangan pakai sabun masih merupakan sasaran penting dalam promosi kesehatan (Djarkoni, et al., 2014).
} 
Mikroorganisme yang terdapat di permukaan kulit dan di sekeliling lingkungan dapat menyebabkan banyak penyakit infeksi pada manusia (Rachmawati \& Triyana, 2008). Tangan yang bersentuhan langsung dengan kotoran manusia dan binatang, ataupun cairan tubuh lain seperti ingus, dan makanan/minuman yang terkontaminasi saat tidak dicuci dengan sabun dapat memindahkan bakteri, virus, dan parasit pada orang lain yang tidak sadar bahwa dirinya sedang ditularkan (Kemenkes RI, 2014).

Cuci tangan pakai sabun yang dipraktikkan secara tepat dan benar merupakan cara termudah dan efektif untuk mencegah berjangkitnya penyakit seperti diare, kolera, ISPA, cacingan, flu, hepatitis A, dan bahkan flu burung. Mencuci tangan dengan air dan sabun dapat lebih efektif menghilangkan kotoran dan debu secara mekanis dari permukaan kulit dan secara bermakna mengurangi jumlah mikroorganisme penyebab penyakit seperti virus, bakteri dan parasit lainnya pada kedua tangan. Oleh karenanya, mencuci tangan dengan menggunakan air dan sabun dapat lebih efektif membersihkan kotoran dan telur cacing yang menempel pada permukaan kulit, kuku dan jari-jari pada kedua tangan (Desiyanto, et al., 2013)

Sabun cair cuci tangan terkandung zat-zat yang bersifat bakterisid dan bakteriostatik. Zat-zat tersebut seperti antibakteri. Selain itu, derajat keasaman $(\mathrm{pH})$ sabun cair cuci tangan juga berperan dalam menghambat pertumbuhan dan membunuh bakteri (Fazlisia, 2014).

TricIosan (2,4,4-trichloro-2-hydroxydiphenyl-ether) merupakan bahan antiseptik yang dikembangkan pertama kali pada tahun 1960 dan telah digunakan dalam berbagai produk kesehatan, seperti sabun, pasta gigi, obat kumur, kosmetik, dan lain sebagainya. Triclosan aktif melawan berbagai bakteri Gram positif maupun Gram negatif, namun pengaruhnya terhadap bakteri Gram positif lebih besar. Antiseptik yang mengandung triclosan dalam konsentrasi kurang dari $2 \%$ biasanya dapat ditoleransi dengan baik dan jarang menimbulkan reaksi alergi, sehingga penyediaan triclosan sebagai bahan antiseptik untuk mencuci tangan (Utami, 2007).

Sabun cair cuci tangan disediakan diberbagai fasilitas umum sudah mengalami proses pengenceran dengan jumlah yang berbeda-beda. Pengenceran sabun cair cuci tangan mengubah $\mathrm{pH}$, konsentrasi antiseptik dan antibakteri sebagai kandungan tambahan yang terlarut di dalam sabun sehingga akan mempengaruhi kemampuan sabun dalam menghambat dan membunuh bakteri (Fazlisia, 2014).

Penelitian yang dilakuan oleh Anisha Fazlisia (2014) mengenai uji daya hambat sabun cair cuci tangan pada restoran waralaba di Kota Padang terhadap pertumbuhan bakteri Escherichia coli dan Staphylococcus aureus secara in vitro, didapat kesimpulan bahwa Semua sampel sabun cair cuci tangan yang berasal dari restoran waralaba di Kota Padang yang telah mengalami pengenceran dapat menghambat pertumbuhan bakteri Staphylococcus aureus dan Escherichia coli.

\section{Metode Penelitian}

Penelitian ini bersifat Observasional Deskriptif yaitu penelitian yang dilakukan dengan tujuan utama yaitu untuk mendiskripsikan atau menggambarkan suatu keadaan secara objektif didalam suatu komunitas atau masyarakat. Metode Observasional Deskriptif digunakan untuk membuat penilaian terhadap suatu program dimasa sekarang, kemudian hasilnya digunakan untuk menyusun perencanaan perbaikan program tersebut (Notoatmodjo, 2012). Rancangan yang digunakan adalah One Group Pretest Posttest yang tidak menggunakan kelompok pembanding (kontrol), tetapi paling tidak telah dilakukan observasi pertama (pretest) yang memungkinkan menguji perubahan-perubahan yang terjadi setelah adanya eksperiment (program). Bentuk rancangan ini adalah sebagai berikut (Hanafiah, 2010) :

\section{Hasil Penelitian}

Hasil penelitian pengaruh pengenceran sabun cair cuci tangan terhadap Angka Lempeng Total Bakteri (ALTB) telapak tangan dapat dilihat pada tabel 1 sebagai berikut : 
Tabel 1. Hasil Angka Lempeng Total Bakteri (ALTB) Telapak Tangan Sebelum dan Setelah Perlakuan

\begin{tabular}{|c|c|c|c|c|}
\hline \multirow{2}{*}{ No. } & \multirow{2}{*}{$\begin{array}{c}\text { Konsentrasi } \\
\text { Cairan Cuci } \\
\text { Tangan }\end{array}$} & \multicolumn{2}{|c|}{$\begin{array}{c}\text { Angka Lempeng Total Bakteri } \\
(\mathrm{Cfu} / \mathrm{ml})\end{array}$} & \multirow{2}{*}{$\begin{array}{c}\text { Penurunan Jumlah Bakteri } \\
(\Sigma \text { sebelum }-\Sigma \text { setelah) }\end{array}$} \\
\cline { 2 - 4 } & $\begin{array}{c}\text { Sebelum Cuci } \\
\text { Tangan }\end{array}$ & $\begin{array}{c}\text { Setelah Cuci } \\
\text { Tangan }\end{array}$ & \\
\hline 1. & $100 \%$ & 2350 & 250 & 2150 \\
\hline 2. & $80 \%$ & 2280 & 370 & 800 \\
\hline 3. & $40 \%$ & 2150 & 1350 & 330 \\
\hline 4. & $20 \%$ & 2970 & 2640 & 160 \\
\hline 5. & $10 \%$ & 2820 & 2660 & 1070 \\
\hline
\end{tabular}

\section{Pembahasan}

Berdasarkan tabel 1. dari perhitungan Angka Lempeng Total Bakteri (ALTB) telapak tangan sebelum dan setelah perlakuan didapatkan hasil Angka Lempeng Total Bakteri (ALTB) telapak tangan pada konsentrasi sabun cair cuci tangan 100\% sebelum cuci tangan sebanyak $2350 \mathrm{Cfu} / \mathrm{ml}$ dan setelah cuci tangan sebanyak $250 \mathrm{Cfu} / \mathrm{ml}$. pada konsentrasi sabun cair cuci tangan $80 \%$ sebelum cuci tangan sebanyak $2280 \mathrm{Cfu} / \mathrm{ml} \mathrm{dan}$ setelah cuci tangan sebanyak $370 \mathrm{Cfu} / \mathrm{ml}$. Pada konsentrasi sabun cair cuci tangan $40 \%$ sebelum cuci tangan sebanyak $2150 \mathrm{Cfu} / \mathrm{ml}$ dan setelah cuci tangan sebanyak $1350 \mathrm{Cfu} / \mathrm{ml}$. pada konsentrasi sabun cair cuci tangan 20\% sebelum cuci tangan sebanyak $2970 \mathrm{Cfu} / \mathrm{ml}$ dan setelah cuci tangan sebanyak $2640 \mathrm{Cfu} / \mathrm{ml}$. pada konsentrasi sabun cair cuci tangan $10 \%$ sebelum cuci tangan sebanyak $2820 \mathrm{Cfu} / \mathrm{ml}$ dan setelah cuci tangan sebanyak $2660 \mathrm{Cfu} / \mathrm{ml}$. Setelah dikurangi antara jumlah koloni sebelum dan setelah cuci tangan didapatkan hasil penurunan jumlah Angka Lempeng Total Bakteri (ALTB) tertinggi pada konsentrasi 100\% yaitu sebanyak $2150 \mathrm{Cfu} / \mathrm{ml}$ dan hasil penurunan jumlah Angka Lempeng Total Bakteri (ALTB) terendah pada konsentrasi $10 \%$ yaitu sebanyak $160 \mathrm{Cfu} / \mathrm{ml}$.

\section{Kesimpulan}

Didapatkan jumlah Angka Lempeng Total Bakteri (ALTB) telapak tangan setelah mencuci tangan menggunakan sabun dengan konsenrasi $100 \%$ sebanyak $250 \mathrm{Cfu} / \mathrm{ml}$.Didapatkan jumlah Angka Lempeng Total Bakteri (ALTB) telapak tangan setelah mencuci tangan menggunakan sabun dengan konsenrasi $80 \%$ sebanyak $370 \mathrm{Cfu} / \mathrm{ml}$. Didapatkan jumlah Angka Lempeng Total Bakteri (ALTB) telapak tangan setelah mencuci tangan menggunakan sabun dengan konsenrasi $40 \%$ sebanyak $1350 \mathrm{Cfu} / \mathrm{ml}$. Didapatkan jumlah Angka Lempeng Total Bakteri (ALTB) telapak tangan setelah mencuci tangan menggunakan sabun dengan konsenrasi 20\% sebanyak $2640 \mathrm{Cfu} / \mathrm{ml}$. Didapatkan jumlah Angka Lempeng Total Bakteri (ALTB) telapak tangan setelah mencuci tangan menggunakan sabun dengan konsenrasi $10 \%$ sebanyak $2660 \mathrm{Cfu} / \mathrm{ml}$. Ada pengaruh pengenceran sabun cair cuci tangan terhadap Angka Lempeng Total Bakteri (ALTB) telapak tangan. Peningkatan jumlah pengenceran berbanding lurus dengan peningkatan jumlah bakteri yang tumbuh dan berbanding terbalik dengan kemampuan sabun cair cuci tangan untuk menghambat pertumbuhan bakteri.

\section{Referensi}

Badan Standarisasi Nasional. 1996. Standar Mutu Deterjen Sintetik Cair Pencuci Tangan Sni 06-2588-1992. Badan Standarisasi Nasional. Jakarta.

Bibiana, W. L. 1994. Analisis mikroba dilaboratorium. Rajawali press. Jakarta.

Brewer, C. 2010. Variations in Phenol Coefficient Determinations of Certain Disinfectants. American Journal of Public Health. 33(1): 261.

Campbell, J. B. Reece, L. G dan Mitchell. 2004. Biologi Edisi Kelima Jilid 3. Erlangga. Jakarta

Damanik SM. 2011. Kepatuhan Hand Hygiene Di Rumah Sakit Immanuel Bandung. Universitas Padjajaran. Bandung.

Darmadi. 2008. Infeksi Nosokomial : Problematika Dan Pengendaliannya. Salemba Medika. Jakarta. 
Depkes RI. 2011. Biasakan Mencuci Tangan Menggunakan Sabun Pada Lima Waktu Kritis. Http://www.depkes.go.id/index.php/component/content/article/43-newsslider/1694-biasakan-cuci-tanganpakai-sabun-pada-5-waktu-kritis.html.

Desiyanto, F.A., Djannah, S.N. 2013. Efektivitas Mencuci Tangan Menggunakan Cairan Pembersih Tangan Antiseptik (Hand Sanitizer), 7(2), 75-82.

Djarkoni, I.H., Lampus, B.S., Siagian, I.E., Kaunang, W.P.J., Palandeng, H. 2014. Hubungan Perilaku Cuci Tangan Pakai Sabun Dengan Kejadian Diare Di SD Adven Sario Kota Manado. Jurnal Kedokteran dan Topik, volume 2, nomor 3, tahun 2014. Hlm. 97-98.

Fardiaz, S. 1993. Mikrobiologi Pangan I. PT Gramedia Pustaka Utama. Jakarta

Fazlisia, A. 2014. Uji Daya Hambat Sabun Cair Cuci Tangan Pada Restoran Waralaba Di Kota Padang Terhadap Pertumbuhan Bakteri Escherichia Coli Dan Staphylococcus Aureus Secara In Vitro. Jurnal kesehatan andalas, 3(3), 348-353.

Fitri, 1. 2009. Kemampuan Daya Hambat Beberapa Macam Sabun Antiseptik Terhadap Pertumbuhan Staphylococcus aureus dan Escherichia coli. Universitas Syiah Kuala.

FKUI, 1994. Buku Ajar Mikrobiologi Kedokteran. Edisi Revisi. Jakarta : Binarupa Aksara.

Hanafiah A. K. 2010. Rancangan Percobaan Teori dan Aplikasi. Rajawali Pers. Jakarta.

Harti, A. S. 2015. Mikrobiologi Kesehatan; Peran Mikrobiologi Dalam Bidang Kesehatan. ANDI. Yogyakarta.

Jawetz, Melnick, \& Adelberg’s. 2010. Mikrobioloi Kedokteran. Penerbit buku kedokteran EGC. Jakarta.

Kemenkes RI. (2014). Perilaku Mencuci Tangan Pakai Sabun Di Indonesia. Pusat Data Dan Informasi. Retrieved from. Http://www.depkes.go.id/resources/download/pusdatin/infodatin/infodatin-ctps.pdf

Michael J., Pelczar, Jr., dan E.C.S. Chan. 2009. Dasar-Dasar Mikrobiologi. UI Press. Jakarta.

Notoatmodjo, S. 2010. Metodelogi Penelitian Kesehatan. Rineka Cipta. Jakarta.

Purwanto, R. H. 2014. Corynebacterium Diphteriae. Diagnosiss Laboratorium Mikrobiologi. Yayasan Pustaka Obor Indonesia. Jakarta.

Purwoko, Susi. 2013. Antioksidan; Manfaat Vitamin C Dan E Bagi Kesehatan. ARCAN. Jakarta.

Pusat Pendidikan Tenaga Kesehatan. 1989. Bakteriologi Umum. Jakarta.

Rahmawati, F. J., dan Triana. 2008. Perbandingan Angka Kuman Pada Cuci Tangan Dengan Beberapa Bahan Sebagai Standarisasi Kerja Dilaboratorium Mikrobiologi Fakultas Kedokteran Universitas Islam Indonesia. Jurnal Penelitian dan Pengabdian. Vol. 5(1). Fakultas Kedokteran. Universitas Islam Indonesia. Yogyakarta.

Rosen, J. Milton. 2004. Surfactant and Interfacial Phenomena. Third edition. John Wiley \& Sons, Inc.

Roslan, A. N., Sunariani J. dan Irmawati A. 2009. Penurunan Sensitivitas Rasa Manis Akibat Pemakaian Pasta Gigi yang Mengandung Sodium Sauryl Sulphate 5\%. Jurnal PDGI Vol. 58 No. 2 hal. 10-13 | ISSN 0024- 9548.

Sarach, R. 2015. Pengaruh Penyuluhan Tentang Cuci Tangan Pakai Sabun (CTPS) Terhadap Sikap Pencegahan Diare Pada Siswa Kelas V SDN Triharjo Sleman Tahun 2015. Naskah Publikasi Stikkes 'Aisyiyah Yogyakarta. 
Sastrosoebroto, Ika. 2013. Public Relations Tiles; Strategi Public Relations Yang Menginspirasi. Raih Asa Sukses (Penebar Swadaya Grup). Jakarta.

Soemarno. 2000. Isolasi Dan Identifikasi Bakteri Klinik. Akademi Analis Kesehatan Yogyakarta. Yogyakarta.

Staf Pengajar Departemen Farmakologi Fakultas Kedokteran Universitas Sriwijaya. 2004. Kumpulan Kuliah Farmakologi Ed. 2. EGC. Jakarta.

Sursilah, Ilah. 2010. Pencegahan Infeksi Dalam Pelayanan Kebidanan. Dee publish. Yogyakarta.

Suryani, A., Hambali E. \& Rivai, M. 2002. Teknologi Produksi Surfaktan. IPB. Bogor.

Susiati. 2008. Keterampilan Keperawatan Dasar Paket 1. Erlangga Medical Series. Jakarta

Utami, 1. 2007. Uji Efektivitas Antiseptik Triclosan 1\% terhadap Stuphylococcus aureus, Escherichia coli, Enterococcus fueculis, dan Pseudomonas ueruginosa. Artikel penelitian IDI.

Waluyo, Lud. 2010. Teknik Dasar dalam Mikrobiologi. UMM Press. Malang.

Wasitaatmadja. 1997. Penuntun Ilmu Kosmetik Medik. Jakarta Pusat: UI Press.

Wati, Meili et al. 2007. Perbandingan Aktivitas Antimikroba Isopropanol, Chloroxylenol, Dan Triclosan Terhadap Staphylococcus aureus Secara Invitro. Bandung.

WHO. 2009. on Hand Hygiene in Health Care First Global Patient Safety Challenge Clean Care is Safer Care. World Health, 30(1), 270. https://doi.org/10.1086/600379 